Горбань А.В., Маранов О.В., Клочков Ю.П., Дорофєєва З.Я.

\title{
ІНФОРМАЦІЙНЕ ЗАБЕЗПЕЧЕННЯ ДЛЯ МОНІТОРИНГУ ТА УПРАВЛІННЯ РУХОМ СУДЕН $З$ ВИКОРИСТАННЯМ ДАНИХ СУПУТНИКОВОЇ НАВІГАЦІЇ
}

У статті досліджена можливість інформачійного забезпечення для моніторингу та управління рухом суден з використанням даних супутникової навігації. Розглянуті елементи системи безпеки судноводіння. Вирімення завдань, пов'язаних з безпекою судноводіння і своєчасною доставкою вантажів, екологічним захистом прибережної зони, вимагає чіткого моніторингу руху суден і управління швидкостями потоків судів або окремих суден. Для иієї мети необхідне впровадження нових сучасних радіотехнічних засобів на базі високоточних супутникових навігаційних технологій та застосування систем, які забезпечують безпеку плавання судів. Дані обставини вимагають створення в регіонах систем керування судноплавством з таким навігаційним забезпеченням, яке б у максимальному ступені знижувало ризик аварій судів при плаванні в прибережних водах, на підходах до портів, у портових водах, у вузкостях, на внутрішніх водних шляхах, де свобода маневрування обмежена. У дослідженні представлене рішення актуальної наукової задачі з розробки математичного забезпечення формування високоточних полів місцевизначення, річкової диференціальної підсистеми GPS, для створення суцільних високоточних телекомунікаційних полів у СX та ПХ діапазонах з урахуванням впливу полі компонентної підстилаючої поверхні, параметрів приймально-передаючого обладнання та урахування загоризонтної рефракції, яка має важливе значення для водного транспорту.

\section{Ключові слова:}

Постановка проблеми. Однієї 3 найважливіших проблем сучасного внутрішнього водного транспорту є забезпечення потрібного рівня безпеки плавання при навігації, як у морських районах, так і на внутрішніх водних шляхах (ВВШ) при відповідному рівні організації транспортного процесу в цілому. Це пояснюється збільшенням інтенсивності судноплавства на ВВШ (особливо на р. Дніпро та портах Одеса, Південний, Маріуполь), впровадженням сучасних, більш швидкісних, збільшеної вантажопідйомності річкових суден та суден "ріка-море" плавання. Сучасне ефективне конструктивне рішення завдань навігації полягає у переході від лоцманського до інструментального методу судноплавства на ВВШ, що базується на використанні електронно-картографічних систем, систем високоточного позиціонування на основі супутникових радіонавігаційні системи GPS $\mathrm{i} 3$ впровадженням у процес управління та моніторингу інфокомуникаційних систем.

Впровадження даних систем неможливо без сформованого в їх зоні дії суцільного поля диференціальної поправки. В акваторіях ВВШ України таке поле може бути сформоване у середньохвильовому (CX) діапазоні контрольно-коригувальними станціями (ККС) локальної диференціальної підсистеми (ЛДПС) GPS. У такий спосіб для забезпечення більш високого рівня безпеки судноплавства, повноцінного моніторингу та управління транспортним процесом на ВВШ одній 3 найбільш актуальних завдань $є$ створення топології зон дії ККС ЛДПС, які використовується для передачі коригувальної інформації у СX діапазоні. Реалізація даного завдання безпосередньо пов'язана з урахуванням впливу підстилаючих поверхонь, загоризонтної рефракції та параметрів інфокомунікаційного обладнання на процес передачі 114 
коригувальної інформації поверхневою хвилею CX діапазону. Отже при побудові практично будь-яких інфокомунікаційних систем та їх функціональних доповнень існує необхідність якісного визначення топології комплексного радіонавігаційного поля високоточного позиціонування з урахуванням часткових варіацій зон дії всіх ККС ЛДПС, які приймають участь у створенні даного поля, у тому числі визначити дальність передачі диференціальних виправлень у СВ та проміжно хвильовому (ПХ) діапазоні. Це безпосередньо пов'язано із забезпеченням безпеки судноплавства та оптимізацію планування транспортного процесу на ВВШ.

Аналіз останніх досліджень і публікацій. Супутниковій навігації присвячена значна кількість наукових робіт, проте поза увагою лишається моніторинг та управління судном з використанням даних супутникової навігації.

Метою статті $\epsilon$ підвищення безпеки судноплавства на ВВШ шляхом обгрунтування створення суцільних високоточних телекомунікаційних полів у СX 3 урахуванням впливу полікомпонентної підстилаючої поверхні, параметрів прийомопередаючого обладнання та урахування загоризонтної рефракції.

Виклад основного матеріалу дослідження. Система безпеки судноводіння (СБС) складається $з$ таких аспектів безпеки як забезпечення внутрішньої і зовнішньої цілісності судна, навігаційної безпеки та попередження зіткнень суден (рисунок 1).

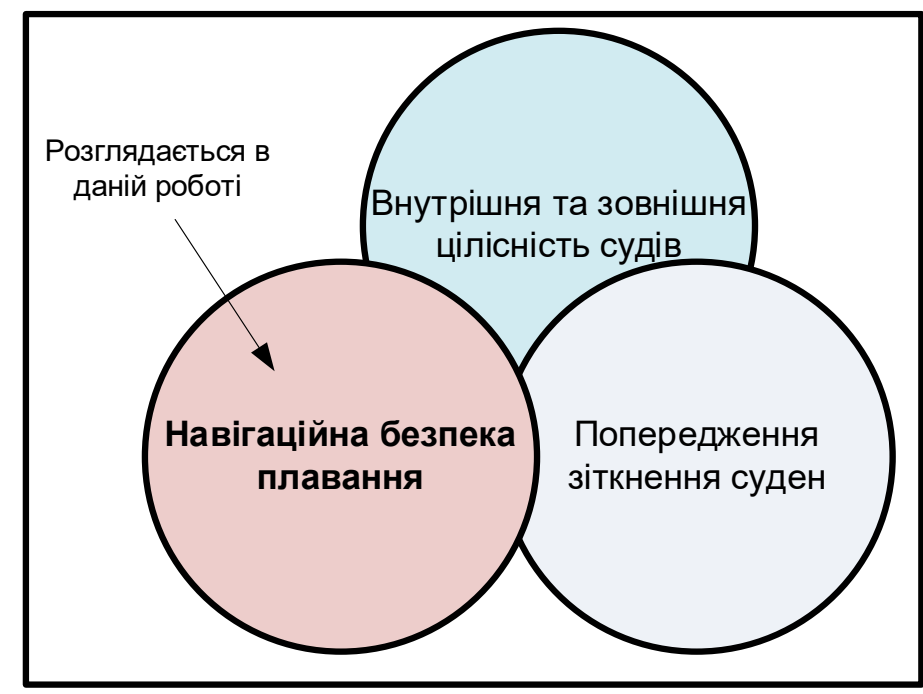

Рисунок 1 - Елементи системи безпеки судноводіння

Навігаційна безпека плавання (НБП) - стан судна в конкретних обставинах та умовах, коли забезпечується мінімальний ризик посадки судна на мілину, торкання грунту, зіткнення зі штучною або природною перешкодою, виходу судна в результаті навігаційних помилок за межі встановленої зони або акваторії. Судно означає кожен описаний плавучий засіб, який використовується або здатний використовуватися як засіб пересування по воді. Крім як мати здатність пересуватися по воді, судно повинне позначати свою присутність і характер дій, виконувати запропоновані МППЗС-72 вимоги в частині несення вогнів, знаків, подачі звукових сигналів, організації спостереження і дій, необхідних для забезпечення безпеки.

Судноводій є управляючою ланкою в структурі судна. На 65-ій сесії Комітету 3 безпеки на морі (вересень 1995 р.) IMO судноводій був представлений як об'єкт впливу ряду різних факторів: "середовища", придбаних навичок та здібностей. Під елементом "навколишнє середовище" розуміється сукупність факторів, які мають різну природу, виконують впливаючі дії, у тому числі і негативний вплив на судно та судноводія, а також можуть призводити до небезпеки зіткнення або загибелі людей.

Взаємозв'язок елементів судно, судноводій i навколишнє середовище, що 
представляють деяку структуру, призначену для прогнозування виникнення небезпечних ситуацій, що мають наслідком руйнування судна, і здатну вживати заходів щодо їх запобігання називається Системою безпеки судноводіння (рисунок 2).

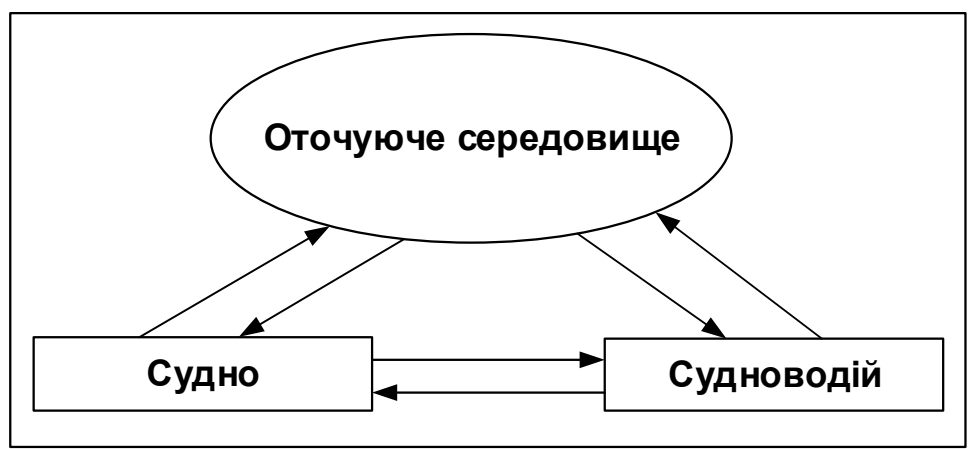

Рисунок 2 - Система безпеки судноводіння

Для рішення проблем аварійності на флоті IMO розробила Систему управління безпекою (СУБ) - структуровану i документовану систему, яка дає можливість персоналу проводити політику судноплавної Компанії в області безпечного управління і захисту навколишнього середовища.

Таким чином, існуюча СУБ побудована на кодексах, конвенціях, постановах та інших законодавчих актах, які містять ряд методологічних формулювань, дозволили побудувати механізм підтримки безпеки мореплавання. Вважається, чим більше бар'єрів на шляху помилок судноводія, тим менше імовірність виникнення аварії або інциденту.

Рішення завдань, пов'язаних 3 безпекою судноводіння (БС) i своєчасною доставкою вантажів, екологічним захистом прибережної зони, вимагає чіткого моніторингу руху суден і управління швидкостями потоків суден або окремих суден. Для цієї мети необхідне впровадження нових сучасних радіотехнічних засобів на базі високоточних супутникових навігаційних технологій та застосування систем, які забезпечують безпеку плавання судів.

Дані обставини вимагають створення в регіонах систем керування судноплавством 3 таким навігаційним забезпеченням, яке б у максимальному ступені знижувало ризик аварій суден при плаванні в прибережних водах, на підходах до портів, у портових водах, у вузькостях, на внутрішніх водних шляхах, де свобода маневрування обмежена.

Технічно це реалізується шляхом будівництва ланцюга контрольнокоригувальних станцій глобальної навігаційної супутникової системи (ГНСС), які забезпечують високоточне навігаційне перекриття судноплавних шляхів, ланцюгів системи управління рухом суден (СУРС), що дозволяють контролювати рух суден у всіх проблемних, 3 погляду навігації, акваторіях, i ланцюгів базових станцій автоматизованих ідентифікаційних систем (AIC), які забезпечують моніторинг морського району уздовж всього узбережжя.

Вимоги до точності місцевизначення судна визначені Резолюцією IMO A.953 (23). Для надійного навігаційного забезпечення суден, безпеки їх плавання, підвищення ефективності їх експлуатації і запобігання екологічних нещасть у прибережних водах, на підходах до портів та внутрішніх водних шляхах похибка місця розташування судна не повинна перевищувати 10 м для $\mathrm{P}=95 \%$. Найбільше повно міжнародним та національним вимогам до навігаційного забезпечення морських $\mathrm{i}$ річкових й споживачів задовольняють ГНСС при роботі в диференційному режимі.

Для забезпечення безпеки судноплавання використовуються контрольні коригувальні станції (ККС). ККС ГНСC GPS призначена для забезпечення безперервного високоточного визначення координат у межах заявленої робочої зони. 
Склад обладнання ККС наведений на рисунку 3.

Контрольна коригувальна станція

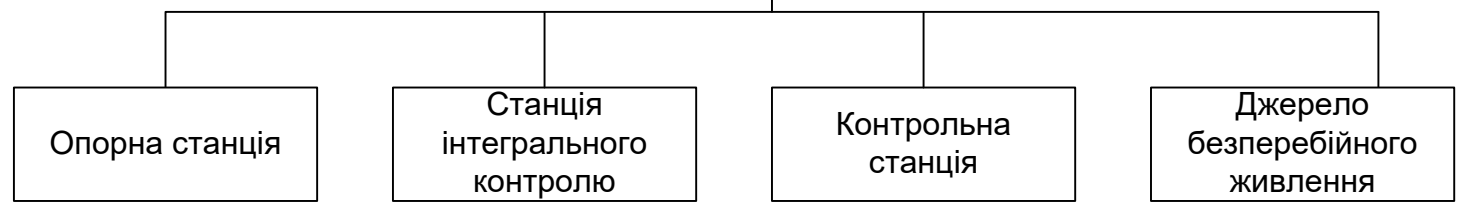

Рисунок 3 - Склад обладнання контрольної коригувальної станції

Основні технічні характеристики елементів, які входять до типового КKC GPS: точність виміру псевдодальності: 0,3 м (1 СКП); точність виміру псевдошвидкості, м/с: 0,04 (1 СКП); інтервал відновлення і видачі даних - <1 с.

Розподіл супутників на орбітах і структура їх сигналів визначають два основних обмеження при виборі місця для розміщення супутникових антен. Опорна станція формує диференціальні поправки для супутників, кути, узвишшя яких над обрієм від $7,5^{\circ}$. Різні будівлі й інші об'єкти можуть викликати затінення антен у горизонтальній площині. Отже, супутникові антени повинні розташовуватися в такому місці, щоб мінімізувати вплив навколишніх об'єктів у горизонтальній площині діаграми спрямованості антен. Другим фактором $є$ ефект багатопроменевості прийнятих сигналів. Ефект виникає за рахунок відображення супутникових сигналів від близько розташованих до антени металевих об'єктів, будівель, що мають добру відбиваючу здатність. Отже, металеві конструкції, щогли та інші предмети, що знаходяться поблизу супутникових прийомних антен, повинні бути вилучені.

У процесі розробки логіко-інформативної моделі системи радіонавігаційного забезпечення безпеки плавання на внутрішніх судноплавних шляхах (ВСШ) необхідно виділити три основні підсистеми: судно, як об'єкт керування; засоби позиціонування, які забезпечують зовнішній зворотний зв'язок, і внутрішні водні шляхи.

Траєкторію руху судна можна розглядати як сукупність прямолінійних i криволінійних ділянок, які характеризуються довжиною, радіусом циркуляції та кутом повороту. При цьому смуга водного шляху $B_{x n}$, займана судном при його русі, $\epsilon$ функцією як власних параметрів судна:

- габаритних розмірів (довжина, ширина, осідання);

- лінійної швидкості руху;

- статичної характеристики керованості;

- динамічних характеристик керованості;

- якості і виду керування (ручного або автоматичне),

так і зовнішніх факторів навколишнього середовища:

- сили та курсового кута вітру;

- швидкості і напрямки плину;

- хвилювання водної поверхні.

Зсув центра ваги (ЦВ) судна $з$ лінії заданого шляху (ЛЗШ), викликане похибками управління і зносом від течії та вітру, визначається величиною $\boldsymbol{У}$, що залежить від методів позиціонування. Зміщення $\boldsymbol{У}$ визначається за даними від зовнішніх джерел інформації, наприклад, по зміщенню судна з лінії лінійного створу, або за результатами обробки радіонавігаційних параметрів, або за даними засобів збереження інформації про рух судна.

3 іншого боку, БС конкретного судна визначається характеристиками водного шляху, такими як:

- ширина суднового ходу $\left(2 B_{c x}\right)$ 
- радіус судового хода $\left(R_{c x}\right)$;

- кут повороту (КП);

- глибина;

- характер грунта;

- характер руху (одно-, двосторонній);

- напрямком та швидкістю течії.

У свою чергу співвідношення характеристик водного шляху та судна, як об'єкта управління, дозволяє зробити розрахунок зони навігаційної безпеки - Д виходячи 3 наступного співвідношення (рис. 4):

$$
\Delta=(B c x-B \sigma)
$$

При розрахунку ширини ходової смуги, займаної судном при проводці 3 урахуванням дрейфу (вітрового і на циркуляції) приймався найбільш несприятливий варіант, коли судно випливає в баласті, а курсовий кут удаваного вітру такий, що викликає максимальний вітровий дрейф $\beta_{\mathrm{B}}$, який, у свою чергу, співпадає за напрямком з дрейфом судна на циркуляції - $\beta_{ц}$.

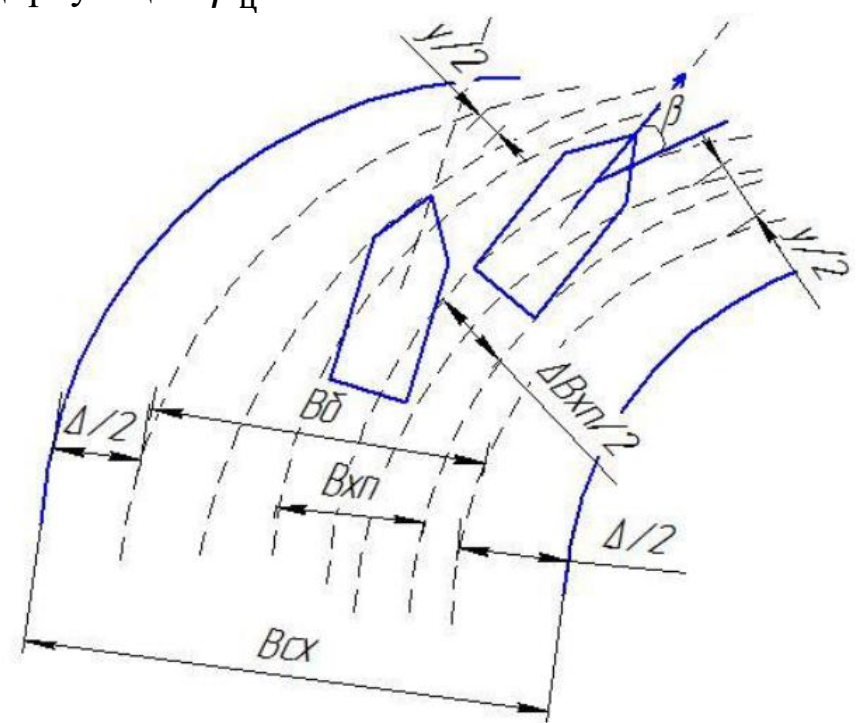

Рисунок 4 - Розрахунок зони навігаційної безпеки

Високочастотна складова похибок управління, коли вектор швидкості судна збігається 3 лінією заданого шляху (рисунок 5, а), призводить до збільшення кута дрейфу судна.

У цьому випадку допустимо приймати значення кута дрейфу, що дорівнює куту рискання судна. Низькочастотна складова похибок управління, коли вектор швидкості судна не співпадає з лінією заданого шляху (рисунок 5, б) призводить до зміщення ЦВ судна на величину $Y$.

Таким чином, відношення характеристик водного шляху та судна дозволяє провести розрахунок зон навігаційної безпеки А та провести оцінку ймовірності відсутності навігаційної події.

При двосторонньому русі по основних судноплавних шляхах припустима СКП при безперервному позиціонуванні складе 3 м при самих несприятливих умовах. Вона представляється деякою мірою завищеною, оскільки похибки управління Уиp отримані при ручному управлінні судном та традиційному методі візуального орієнтування по знаках шляхової обстановки. При необхідності уточнення похибки управління 3 урахуванням допустимої СКП місця судна можна використовувати рівняння руху 
системи автоматичного управління судном на траєкторії з використанням в якості датчика зовнішнього зворотного зв'язку покажчика швидкості повороту (ПШП) та інформації про відхилення ЦВ судна від осі фарватеру.

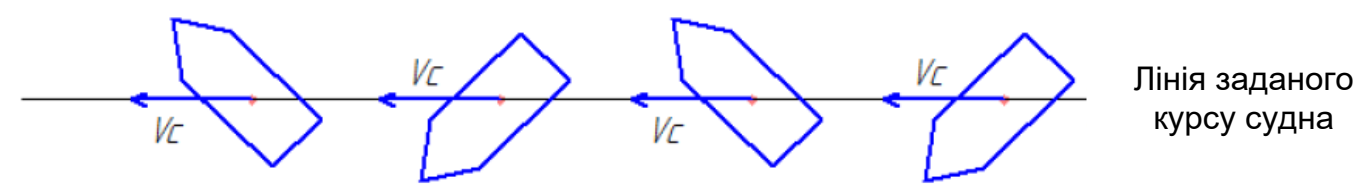

а) Високочастотна складова шляху судна

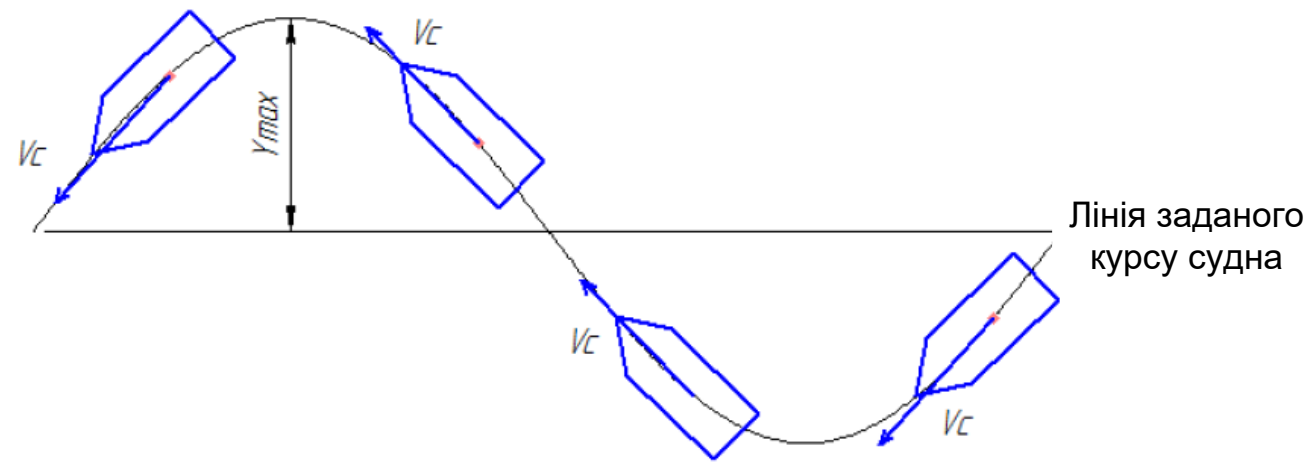

б) Низькочастотна складової похибки управління Рисунок 5 - Похибки управління

На рисунку 6 наведена структурна схема логіко-інформаційної моделі управління 3 урахуванням інерційних характеристик судна та регулятора $\tau$, $, \tau_{\mathrm{p}}, \tau_{3}$, коефіцієнтів передачі судна $K_{c}$ за керуючим впливом, $K_{p}$ - регуляторів $K_{1}, K_{3}, K_{6}$ та $K_{7}$ - відповідно блоків формування закону керування. Таким чином, можна визначити необхідну точність і дискретність позиціонування, тобто сформулювати основні вимоги до радіонавігаційних систем.

При розгортанні диференційних систем необхідно вирішити три основні проблеми:

- забезпечити задану точність визначення координат у робочій зоні з урахуванням можливого росту похибок у залежності від видалення від контрольної точки, для якої вони були визначені;

- оцінити зміни виправлень у часовій області, що дозволить сформулювати вимоги до "часу" виправлень, виходячи з умов точності;

- забезпечити безперервну передачу даних, включаючи диференціальні виправлення, інформацію про цілісність та іншу необхідну інформацію 3 заданою швидкістю і вірогідністю.

Рішення зазначеного вище блоку проблем дозволяє сформулювати концепцію радіонавігаційного забезпечення безпеки плавання судів на ВСШ, включаючи пропозиції з топології системи ККС.

Характерною рисою при русі річкових суден в умовах обмеженої видимості, в системах автоматичного управління курсом (річкових авторулевих) $\epsilon$ застосування покажчиків швидкості повороту (ПШП). Отже, для плавання по обчисленню на ВСШ використовується інформація про кутову та лінійну швидкості судна.

На відміну від морських умов, на ВСШ при русі на криволінійних ділянках інформація тільки від засобів числення не забезпечує безпеки плавання. Також апроксимація маршруту відрізками прямих ліній на ВСШ недостатня. У формат шляхових точок повинен закладатися радіус повороту, кут повороту та маршрутні 
координати $\boldsymbol{X}$ початку повороту. У випадках, коли поворот судна буде зроблений 3 погрішністю за часом $\Delta t$, це приведе до зсуву точки повороту уздовж осі суднового ходу.

Результати досліджень, виконані з використанням логіко-інформаційної моделі представлені в таблиці 1.

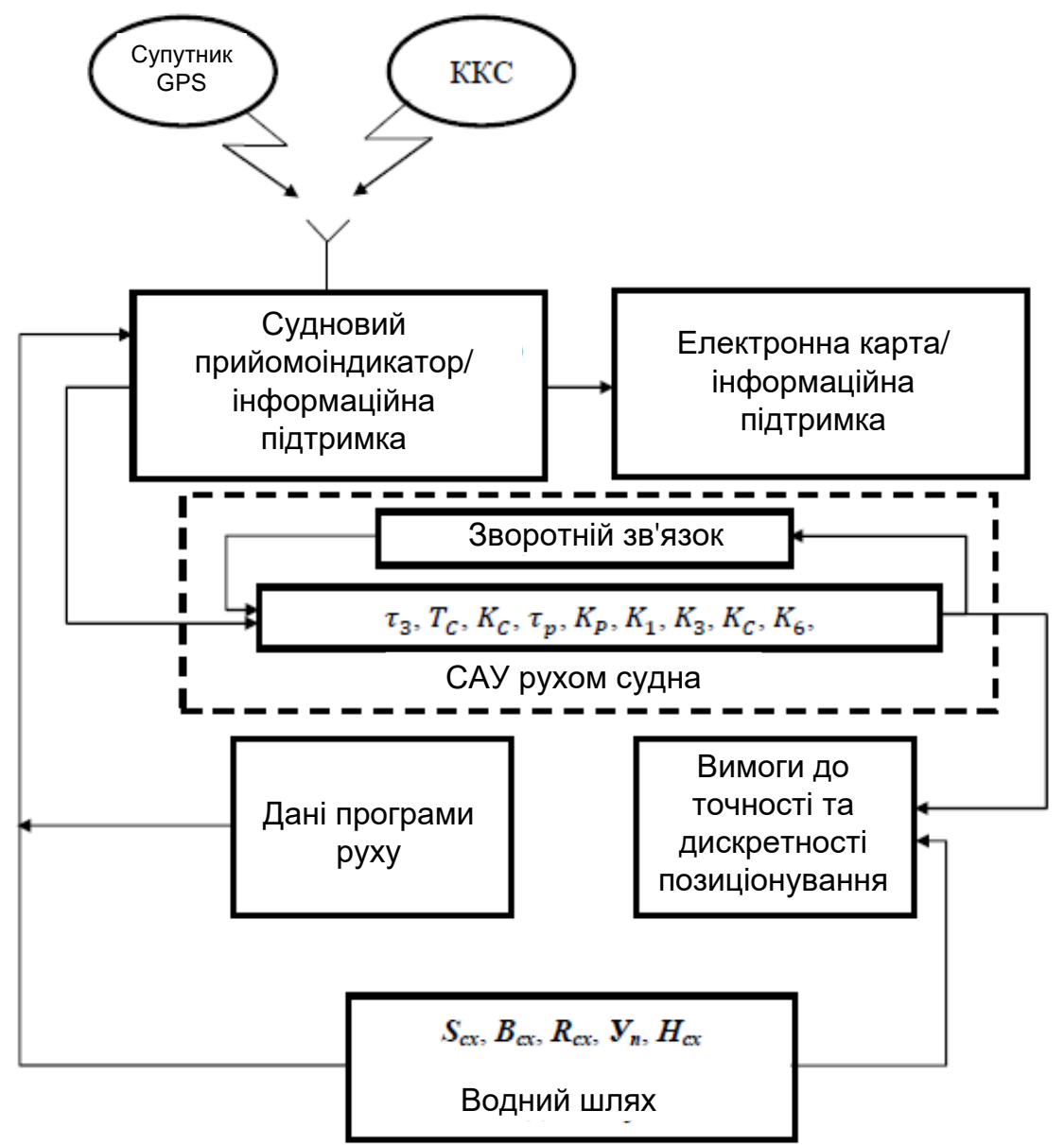

Рисунок 6 - Логіко-інформаційна модель управління рухом судна

Таблиця 1 - Результати досліджень, виконані з використанням логіко-інформаційної моделі

\begin{tabular}{|c|c|c|}
\hline $\begin{array}{l}\text { Завдання, які } \\
\text { вирішуються }\end{array}$ & Райони плавання & $\begin{array}{c}\text { Радіальна похибка позиціонування, м } \\
(\mathrm{P}=0,95)\end{array}$ \\
\hline \multirow{3}{*}{$\begin{array}{c}\text { Рух судна по внутрішніх } \\
\text { водних шляхах }\end{array}$} & 1. Озера та водоймища & $25,0-45,0$ \\
\hline & 2. Річки & $5,0-10,0$ \\
\hline & 3. Канали & $2,0-5,0$ \\
\hline \multirow{3}{*}{$\begin{array}{c}\text { Розміщення знаків } \\
\text { судноплавної обстановки і } \\
\text { визначення габаритів ВВШ }\end{array}$} & 1. Озера и водоймища & $2,5-4,5$ \\
\hline & 2. Річки & $0,5-1,0$ \\
\hline & 3. Канали & $0,3-0,5$ \\
\hline
\end{tabular}

Таким чином, для забезпечення безпеки плавання на ВВП, за винятком особливо скрутних для судноплавства ділянок, радіальна похибка позиціонування не повинна перевищувати 10 м (з $P=0,95)$ при дискретності обсервації 5-10 с з використанням засобів числення і 1-2 с при безпосередньому керуванні судном по сигналах ГНСС (індикаторний режим). 
При ширині суднового ходу більш 80-100 м, коли забезпечення імовірності відсутності навігаційної події значно більш, ніж 0,997, тобто коли критерій безпеки руху виконаний, варто брати до уваги так званий економічний критерій, який мінімізує пропульсивні втрати судна на ділянці маршруту в залежності від точності позиціонування та методів управління.

Природно, що на основі аналізу результатів натурних іспитів у реальних умовах плавання розроблена дана модель забезпечення безпеки буде уточнюватися та вдосконалюватися.

При використанні диференціальних методів позиціонування виключаються систематичні похибки. Тому точність виправлень у робочій зоні буде визначатися:

- випадковими похибками у контрольній точці та у місці прийому на судні;

- ростом похибки у залежності від дистанції до контрольної точки, у якій вони були визначені;

- змінами похибок у часовій області.

Перераховані вище випадкові похибки призводять до еквівалентної похибки

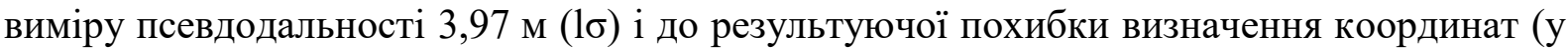
горизонтальній площині) у 4 м при геометричному факторі, що дорівнює трьом.

Найбільший вплив на похибку буде робити зміна кута піднесення супутника - Е. Ця зміна буде максимальною при розташуванні судна, контрольної точки та супутника в одній площині (рис. 7).

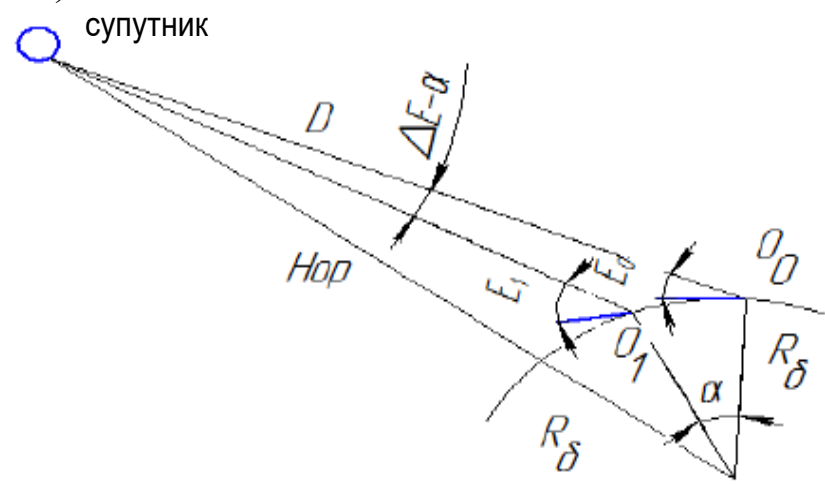

Рисунок 7 - Вплив на похибку зміни кута піднесення супутника

Аналіз результатів розрахунку показує, щоб дотримати порядку точності системи при видаленні понад 500-700 км від контрольної точки варто обмежити використання супутників з кутами піднесення більше за $10^{\circ}$. Отримані результати мають потребу в експериментальній перевірці з урахуванням часу доби, географічної широти, часу року та фази циклу сонячної активності, забезпечення в робочій зоні потрібну точність 3 ймовірністю 0,95 .

При часі дифпоправки до $10 \ldots 15$ с зміна швидкості іоносферної та тропосферної затримок істотного значення на точність позиціонування не має. Деградація похибки при віддаленні від контрольної точки з 100 км до 500 км збільшується в 5 разів при кутах підвищення супутників.

Одним з найважливіших експлуатаційних параметрів локальних диференціальних підсистем системи зв'язку та радіонавігації, що працюють у СX діапазоні, $\epsilon$ форма периметра зони дії. Як правило, іiі визначають шляхом розрахунку дальності поширення сигналу ККС, що містить коригувальну інформацію 3 урахуванням параметрів приймально-передаючого обладнання.

На процеси поширення поверхневих радіохвиль, особливо у СХ діапазоні, значно впливає підстилаюча поверхня, над якою здійснюється поширення таких радіохвиль. Підстилаюча поверхня володіє неоднорідними електромагнітними властивостями. Однак таку поверхню можна представить у виді кусочно-однорідної поверхні, де кожна 3 ділянок має достатню довжину в порівнянні 3 довжиною радіохвилі $\lambda$. У такому 
випадку будемо вважати перехідні області між ділянками досить малими в порівнянні 3 довжиною хвилі.

Ефективні значення параметрів підстилаючої поверхні визначаються не тільки характером грунту, але й вмістом у ній вологи, температурою грунту, робочою частотою, загальною геологічною структурою земної поверхні, ефективною глибиною проникнення радіохвилі в грунт та бічний розкид хвиль. Крім того, поглинання електромагнітної енергії може бути досить значним при поширенні радіохвилі над поверхнею заповненою рослинністю (ліс, чагарник, тощо), будинками, а також іншими особливостями рельєфу.

Вміст вологи в землі, безсумнівно, є досить значним фактором, що визначає іiі електричні параметри (рисунок 8).
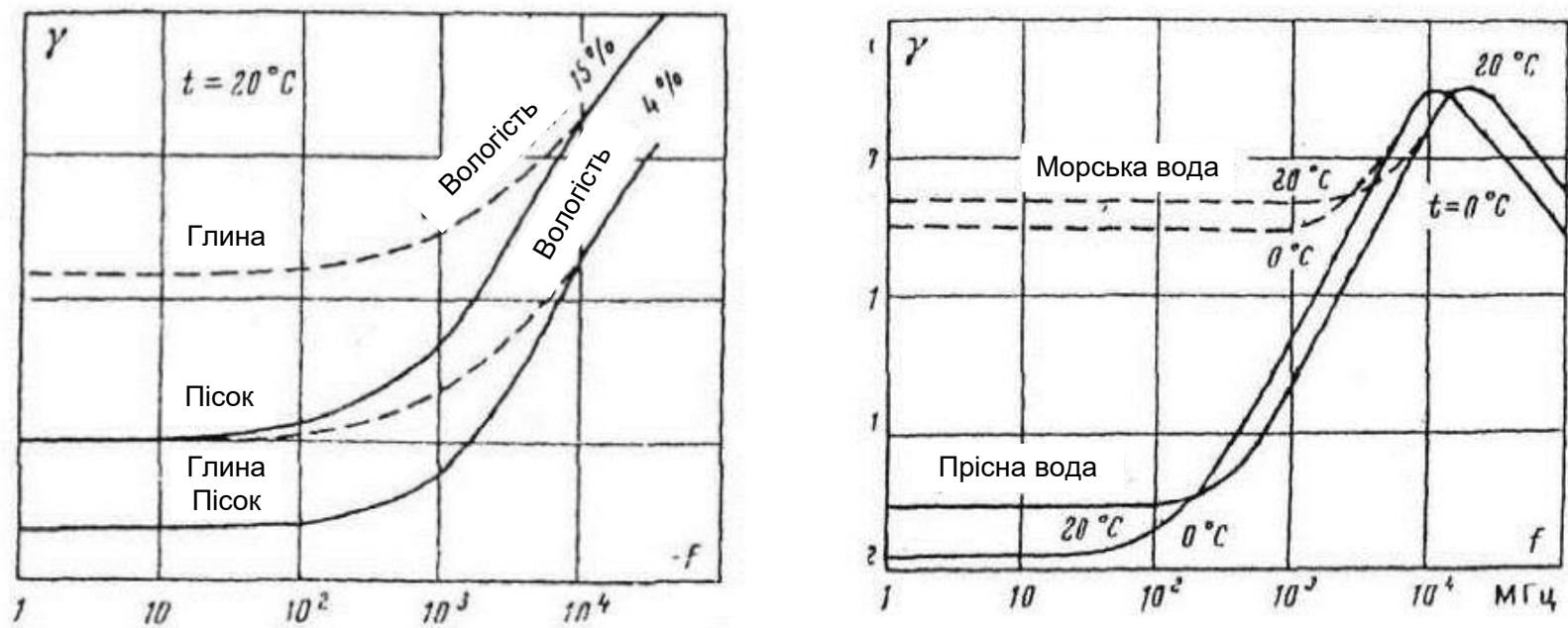

Рисунок 8 - Частотні залежності електричних параметрів грунтів різної вологості

По мірі збільшення вмісту вологи від малої величини параметри провідності грунту покращувалися і досить швидко можуть досягати максимальних значень. На глибині більше метра має місце значна вологість грунту, причому це значення в основному стабільно.

Температурний коефіцієнт провідності зразків грунту різного типу є величиною порядку 2\% на градус шкали Цельсія.

Геологічна структура. Ефективні параметри зони, району або радіотраси, як правило, визначаються не тільки характером поверхневого шару грунту, але i шаруватістю поверхні по глибині.

Вплив непрямих радіотрас. Радіосигнал, прийнятий у точці прийому, як правило, поширюється по декількох радіотрасах. Таким чином, при розрахунку радіолінії необхідно враховувати параметри підстилаючи поверхонь не тільки уздовж основної траси, але також і в зоні проходження непрямих радіотрас.

Предмети, розташовані на поверхні землі, не роблять безпосереднього впливу на електромагнітні властивості підстилаючої поверхні, однак такі перешкоди можуть помітно послабляти радіохвилі, які перетинають їх або поширюються в безпосередній близькості.

Таким чином, проведено аналіз факторів, які впливають на розповсюдження радіохвиль.

Розглянемо алгоритми визначення вертикальної складової напруженості диференціального радіонавігаційного поля.

За допомогою моделі М.В. Шулейкина - В. Ван-дер-Поля представляється можливим розраховувати амплітуду $\mathrm{E}_{\mathrm{m} 1 \mathrm{~B}}$ (вертикального електричного компонента електромагнітного поля) безпосередньо в поверхні землі в точці прийому, коли 
випромінювачем є вібратор розташований поблизу напівпровідної поверхні.

Залежність множника ослаблення від чисельної відстані для різних значень $\operatorname{tg} \delta=$ $60 \gamma \lambda$ / наведена на рисунку 9 для значень $\rho<25$, при значеннях чисельної відстані, що перевищує 25.

Очевидно, що модель М.В. Шулейкина - В. Ван-дер-Поля застосовується для малих відстаней, коли поширення відбувається над однорідною підстилаючою поверхнею та малих значеннях загоризонтної рефракції.

Модель академіка В.А. Фока використовується при великих відстанях, коли поширення радіохвиль відбувається над однорідною підстилаючою поверхнею та за значною загоризонтною дифракцією. У випадку, якщо довжина радіолінії і висоти приймальной та передавальної антен такі, що область, істотна при поширенні радіохвиль (перша зона Френеля), частково або цілком перекриваються опуклістю земної поверхні, то незакрита частина 1-й зони Френеля або зон наступних номерів, які представляють сукупність джерел сферичних хвиль, створюють випромінювання не тільки в напрямку первісного напрямку руху хвилі, але і за опуклістю земної поверхні.

Відстані близькі до межі прямої видимості, коли перша зона Френеля закрита тільки частково, називаються областю півтіні. Відстані, при яких перша зона Френеля перекрита цілком, називаються областю тіні.

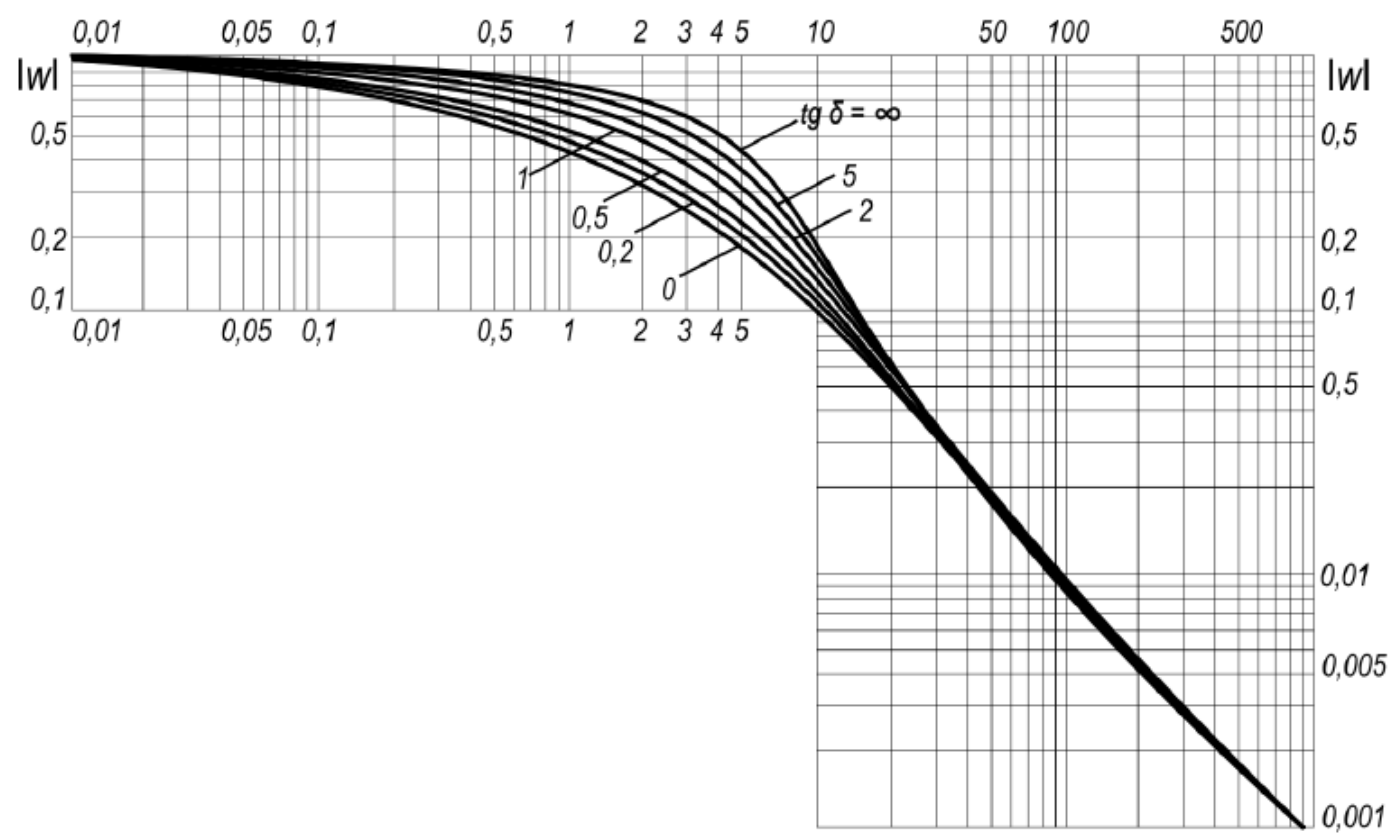

Рисунок 9 - Залежність множника ослаблення від чисельної відстані

Залежність напруженості електромагнітного поля від відстані для різних довжин хвиль та різних електричних параметрів підстилаючої поверхні при потужності передавача 1 кВт наведена на рисунку 10.

Існує модель для розрахунків структури ККС при визначенні радіуса дії цих станцій по допущеннях Шулейкина та Б. Ван-дер-Поля з урахуванням параметрів прийомопередаючих трактів ККС та суднового транспондера.

Для розрахунку дальності дії річкової диференціальної підсистеми ГНСC GPS 3 урахуванням параметрів приймально-передаючого обладнання використаємо співвідношення

$$
r_{c}=0,6 \frac{\lambda^{4}}{\pi} \sqrt{\frac{P_{\text {вип. }}}{\alpha \cdot P_{\text {пр.min }}} \cdot D_{\text {пр }} \cdot D_{\text {пер }} \cdot \frac{\left((\varepsilon-1)^{2}+(60 \gamma \lambda)\right)^{2}}{\varepsilon^{2}+(60 \gamma \lambda)^{2}}} .
$$



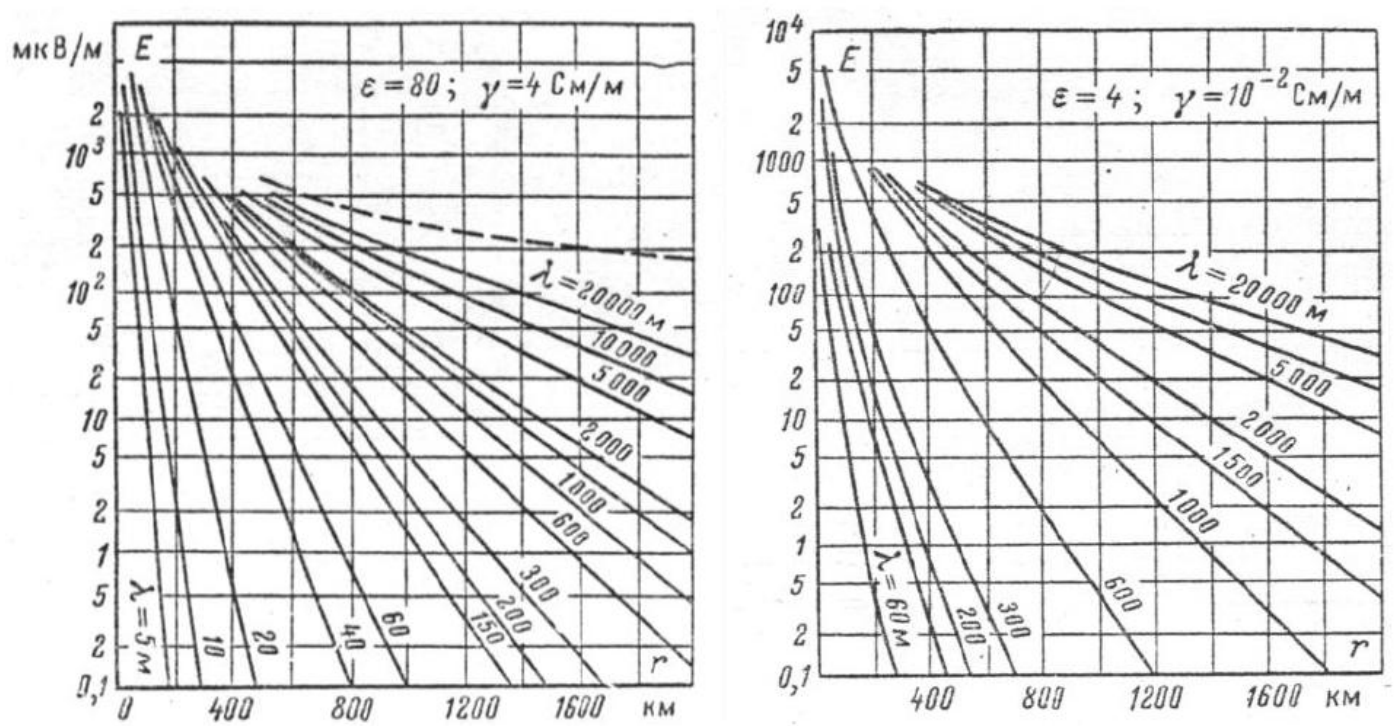

Рисунок 10 - Графіки для визначення напруженості поля поверхневої хвилі, ліворуч при поширенні над морем, праворуч - при поширенні над суходолом

Дане співвідношення може бути покладене в основу розрахунку зони дії в азимутальній площині кожної ККС, оскільки тут враховується зміна властивостей місцевості за напрямком випромінювання поверхневої хвилі за рахунок зміни значень

$\varepsilon$ та $\gamma$.

Висновки. У ході дослідження розроблено структуру логіко-інформаційної моделі системи радіонавігаційного забезпечення безпеки плавання на ВВШ.4. Визначено вимоги до точності і дискретності навігаційного місцезнаходження за сигналами річкової диференціальної підсистеми ГНСC GPS на ВВШ та розроблено алгоритм розрахунку форми периметра зони дії річкової диференціальної підсистеми ГНCC GPS. Визначено особливості впливу властивостей провідності підстилаючої поверхні на дальність передачі коригувальної інформації річковий диференційної підсистеми ГНСC GPS у діапазонах CX та ПХ та особливості точності передачі коригувальної інформації в діапазоні УКХ.

\section{ЛІТЕРАТУРА}

1. Каретников, В.В. Топология дифференциальных полей и дальность действия контрольно-корректирующих станций высокоточного местоопределения на внутренних водных путях /В.В. Каретников, А.А. Сикарев// - СПб.: СПГУВК, 2008. - $352 \mathrm{c}$.

2. Соловьев, Ю.А. Системы спутниковой навигации /Ю.А. Соловьев. - М.: ЭкоТрэнд, 2000. - $267 \mathrm{c}$.

3. Каретников, В.В. Архитектура зон действия локальных дифференциальных подсистем работающих для нужд внутреннего водного транспорта / В.В. Каретников, СПб.: СПГПУ, 2010. - 184 с.

4. Андрюшечкин, Ю.Л. Особенности передачи корректирующей информации в локальных дифференциальных подсистемах/Ю.Н. Андрюшечкин, С.В. Рудых, В.В. Каретников// Журнал «Морская радиоэлектроника Вып. 1(43). -СПб Типография Феникс, 2014. -С 32-34.

5. Сикарев, А.А. Принципы построения функциональных дифференциальных дополнений спутниковых навигационных систем второго и третьего поколений /А.А. Сикарев, А.И. Чернюк// Межвуз. сб. науч. трудов «Технические средства судовождения и связи на морских и внутренних путях». Вып. 5 /под ред. А.А. 
Сикарева. - СПб.: СПГУВК, 2004. - С. 94-100.

6. Андрюшечкин, Ю.Н. Моделирование топологической структуры зон действия контрольно корректирующих станций дифференциальной системы GPS, установлены на реке Обь /Ю.Н. Андрюшечкин, В.В. Каретников // Журнал «Вестник Государственного университета морского и речного флота име-ни адмирала С.О. Макарова» Вып 1.- СПб.: ГУМРФ .2013 - С 86-89.

7. Соловьев, Ю.А. Спутниковая навигация и ее приложения /Ю.А. Соловьев. - М.: Эко-Трэнд, 2003. - 325 с.

8. Ассоциация Электронной Промышленности. Интерфейс между терминальным оборудованием данных и оборудованием передачи данных, применяющий последовательный двоичный обмен данными (EIA RS-232-C), 2001, Ай Стрит, Нью-Йорк, штат Вашингтон, D. C. 2006. 125 с.

9. Vice President Gore Announces. New Global Positioning System Moderni-zation Initiative. The White House, Office of the Vice President, January 25. 1999.

10. Каретников, В. В. К вопросу определения вертикальной составляющей напряженности электромагнитного поля радиоволны в точке приема /B. В. Каретников, А. А. Сикарев// Информационные технологии в транспортных системах: Сб. науч. трудов Рос. акад. транспорта / под ред. А. С. Бутова. - СПб.: СПГУВК, 2002. - С. 46-59.

11. Никитин, М.М. Модель непосредственного расчета дальности действия и зоны покрытия контрольно-корректирующих станций /М.М. Никитин, А.А. Сикарев// Труды Рос.-Польск. НТК «Анализ, прогнозирование и управление в сложных системах». - СПб.: СПГУВК, 2002. - С. 162-167.

12. Никитин, M. М. Алгоритмическое обеспечение расчета параметров радионавигационного электромагнитного поля дифференциальных поправок /М.M. Никитин, А.А. Сикарев// Информа-ционные проблемы транспортных систем: Сб. науч. трудов Рос. акад. транспорта/ под ред. А. С. Бутова. - СПб.: СПГУВК, 2000. - С. 130-133.

13. Каретников, В. В. К вопросу построения зон дифференциальных поправок для подсистемы GPS ГНСC /B. В. Каретников// Технические средства судовождения и связи на морских и внутренних водных путях: Межвуз. сб. науч. трудов / под ред. А.А. Сикарева. - СПб.: СПГУВК, 2002. - Вып. 3. - С. 27-31.

14. Каретников, В. В. Исследование характера нелинейных переходов для вертикальной составляющей дифференциального поля в зависимости от электромагнитных свойств участков подстилающей поверхности /B. B. Каретников// Технические средства судовождения и связи на морских и внутренних водных путях: Межвуз. сб. науч. трудов/ под ред. А. А. Сикарева. СПб.: СПГУВК, 2003. - Вып. 4. - С. 94-100.

15. Каретников, В. В. Обзор возможных методов расчета радиуса действия контрольно-корректирующих станций (ККС) /В. В. Каретников// Технические средства судовождения и связи на морских и внутренних водных путях: Межвуз. сб. науч. трудов/ под ред. А.А. Сикарева. - СПб.: СПГУВК, 2003. - Вып. 4. - С. $115-120$.

\section{REFERENCES}

1. Karetnykov, V.V. Topolohyia dyfferentsyalnykh polei y dalnost deistvyia kontrolnokorrektyruiushchykh stantsyi vysokotochnoho mestoopredelenyia na vnutrennykh vodnykh putiakh /V.V. Karetnykov, A.A. Sykarev// - SPb.: SPHUVK, 2008. - 352 s.

2. Solovev, Yu.A. Systemы sputnykovoi navyhatsyy /Iu.A. Solovev. - M.: Эko-Tpэnd, 2000. - 267 s.

3. Karetnykov, V.V. Arkhytektura zon deistvyia lokalnыkh dyfferentsyalnykh podsystem rabotaiushchykh dlia nuzhd vnutrenneho vodnoho transporta / V.V. Karetnykov, SPb.: 
SPHPU, 2010. - $184 \mathrm{~s}$.

4. Andriushechkyn, Yu.L. Osobennosty peredachy korrektyruiushchei ynformatsyy v lokalnykh dyfferentsyalnykh podsystemakh/Iu.N. Andriushechkyn, S.V. Rudykh, V.V. Karetnykov// Zhurnal «Morskaia radyoelektronyka V. 1(43). -SPb Typohrafyia Fenyks, 2014. -S 32-34.

5. Sykarev, A.A. Pryntsypy postroenyia funktsyonalnykh dyfferentsyalnykh dopolnenyi sputnykovykh navyhatsyonnykh system vtoroho y treteho pokolenyi /A.A. Sykarev, A.Y. Cherniuk// Mezhvuz. sb. nauch. trudov «Tekhnycheskye sredstva sudovozhdenyia y sviazy na morskykh y vnutrennykh putiakh». Vыp. 5 /pod red. A.A. Sykareva. - SPb.: SPHUVK, 2004. - S. 94-100.

6. Andriushechkyn, Yu.N. Modelyrovanye topolohycheskoi struktury zon deistvyia kontrolno korrektyruiushchykh stantsyi dyfferentsyalnoi systemy GPS, ustanovleny na reke $\mathrm{Ob} / \mathrm{Iu} . \mathrm{N}$. Andriushechkyn, V.V. Karetnykov // Zhurnal «Vestnyk Hosudarstvennoho unyversyteta morskoho y rechnoho flota ymeny admyrala S.O. Makarova» V 1.- SPb.: HUMRF .2013 - S 86-89.

7. Solovev, Yu.A. Sputnykovaia navyhatsyia i ee prylozhenyia /Iu.A. Solovev. - M.: ЭkoTpэnd, 2003. - $325 \mathrm{~s}$.

8. Assotsyatsyia elektronnoi Promyshlennosty. Ynterfeis mezhdu termynalnym oborudovanyem dannykh y oborudovanyem peredachy dannыkh, prymeniaiushchyi posledovatelnyi dvoychnyi obmen dannymy (EIA RS-232-C), 2001, Ai Stryt, NiuYork, shtat Vashynhton, D. C. 2006. 125 s.

9. Vice President Gore Announces. New Global Positioning System Modernization Initiative. The White House, Office of the Vice President, January 25. 1999.

10. Karetnykov, V. V. K voprosu opredelenyia vertykalnoi sostavliaiushchei napriazhennosty elektromahnytnoho polia radyovolny $\mathrm{v}$ tochke pryema $/ \mathrm{V}$. $\mathrm{V}$. Karetnykov, A. A. Sykarev// Ynformatsyonnыe tekhnolohyy v transportnykh systemakh: Sb. nauch. trudov Ros. akad. transporta / pod red. A. S. Butova. - SPb.: SPHUVK, 2002. - S. 46-59.

11. Nykytyn, M.M. Model neposredstvennoho rascheta dalnosty deistvyia v zony pokrytyia kontrolno-korrektyruiushchykh stantsyi /M.M. Nykytyn, A.A. Sykarev// Trudy Ros.Polsk. NTK «Analyz, prohnozyrovanye y upravlenye v slozhnykh systemakh». - SPb.: SPHUVK, 2002. - S. 162-167.

12. Nykytyn, M. M. Alhorytmycheskoe obespechenye rascheta parametrov radyonavyhatsyonnoho elektromahnytnoho polia dyfferentsyalnykh popravok /M.M. Nykytyn, A.A. Sykarev// Ynformatsyonnye problemy transportnykh system: Sb. nauch. trudov Ros. akad. transporta/ pod red. A. S. Butova. - SPb.: SPHUVK, 2000. - S. 130 133.

13. Karetnykov, V. V. K voprosu postroenyia zon dyfferentsyalnykh popravok dlia podsystemy GPS HNSS /V. V. Karetnykov// Tekhnycheskye sredstva sudovozhdenyia y sviazy na morskykh y vnutrennykh vodnыkh putiakh: Mezhvuz. sb. nauch. trudov / pod red. A.A. Sykareva. - SPb.: SPHUVK, 2002. - Vыp. 3. - S. 27-31.

14. Karetnykov, V. V. Yssledovanye kharaktera nelyneinykh perekhodov dlia vertykalnoi sostavliaiushchei dyfferentsyalnoho polia $\mathrm{v}$ zavysymosty ot эlektromahnytnykh svoistv uchastkov podstylaiushchei poverkhnosty /V. V. Karetnykov// Tekhnycheskye sredstva sudovozhdenyia y sviazy na morskykh y vnutrennykh vodnykh putiakh: Mezhvuz. sb. nauch. trudov/ pod red. A. A. Sykareva. - SPb.: SPHUVK, 2003. - Vыр. 4. - S. 94 100.

15. Karetnykov, V. V. Obzor vozmozhnykh metodov rascheta radyusa deistvyia kontrolnokorrektyruiushchykh stantsyi (KKS) /V. V. Karetnykov// Tekhnycheskye sredstva sudovozhdenyia y sviazy na morskykh y vnutrennykh vodnykh putiakh: Mezhvuz. sb. nauch. trudov/ pod red. A.A. Sykareva. - SPb.: SPHUVK, 2003. - Vыр. 4. - S. 115120. 
Горбань А.В., Маранов А.В., Дорофеева 3.Я.

ИНФОРМАЦИОННОЕ ОБЕСПЕЧЕНИЕ ДЛЯ МОНИТОРИНГА И УПРАВЛЕНИЯ ДВИЖЕНИЕМ СУДОВ С ИСПОЛЬЗОВАНИЕМ ДАННЫХ СПУТНИКОВОЙ НАВИГАЦИИ

В статье исследована возможность информационного обеспечения для мониторинга и управления движением судов с использованием данных спутниковой навигации. Рассмотрены элементы системы безопасности судовождения. Решение задач, связанных с безопасностью судовождения и своевременной доставкой грузов, экологической защитой прибрежной зоны, требует четкого мониторинга движения судов и управления скоростями потоков судов или отдельных судов. Для этой иели необходимо внедрение новых современных радиотехнических средств на базе высокоточных спутниковых навигачионных технологий и применения систем, обеспечивающих безопасность плавания судов. Данные обстоятельства требуют создания в регионах систем управления судоходством с таким навигационным обеспечением, которое бы в максимальной степени снижало риск аварий судов при плавании в прибрежных водах, на подходах к портам, в портовых водах, в узкостях, на внутренних водных путях, где свобода маневрирования ограничена. В исследовании представлено решение актуальной научной задачи по разработке математического обеспечения формирования высокоточных полей местоопределения, речной дифференииальной подсистемь GPS, для создания сплошных высокоточных телекоммуникационных полей в $C X$ и ПХ диапазонах с учетом влияния поле компонентной подстилающей поверхности, параметров приемо-передающего оборудования и учета загоризонтная рефракции, которая имеет важное значение для водного транспорта

\section{Gorban A.V., Maranov O.V., Klochkov Yu.P., Dorofeeva Z.Ya. INFORMATION SUPPORT FOR MONITORING AND CONTROL OF VESSELS USING SATELLITE NAVIGATION DATA}

The article investigates the possibility of information support for monitoring and control of ship traffic using satellite navigation data. Elements of the navigation safety system are considered. Solving problems related to the safety of navigation and timely delivery of goods, environmental protection of the coastal zone, requires clear monitoring of vessel traffic and management of flow rates of vessels or individual vessels. For this purpose, it is necessary to introduce new modern radio equipment based on high-precision satellite navigation technologies and the use of systems that ensure the safety of navigation. These circumstances require the establishment of navigation control systems in the regions with such navigation support that would minimize the risk of ship accidents while navigating in coastal waters, on approaches to ports, in port waters, in narrows, on inland waterways, where freedom of maneuver is limited. The study presents a solution of an urgent scientific problem to develop mathematical software for the formation of high-precision fields of field, river differential subsystem GPS, to create continuous high-precision telecommunication fields in the CX and $G C$ ranges taking into account the influence of the field component which is important for water transport 